\title{
Haematological levels in Jamaican infants
}

\author{
SALLY M. GRANTHAM-McGREGOR, P. DESAI, and P. F. MILNER \\ From the M.R.C. Epidemiology Unit and the Department of Pathology, University of the West Indies, Kingston, \\ Jamaica
}

\begin{abstract}
Grantham-McGregor, S. M., Desai, P., and Milner, P. F. (1974). Archives of Disease in Childhood, 49, 525. Haematological levels in Jamaican infants. A longitudinal study of 300 infants from birth to 1 year of age was carried out in Kingston, Jamaica. Haemoglobin levels were estimated 7 times during the year and serum iron and total iron binding capacity once. Hb electrophoresis was performed. In singleton children with $\mathrm{Hb}$ genotype AA, AS, or AC, and of birthweight $2.5 \mathrm{~kg}$ or over, $\mathrm{Hb}$ levels were low after 3 months of age. These low levels were associated with iron deficiency, which was probably due to poor iron stores at birth followed by poor iron intake or absorption. It was not possible to determine whether folic acid deficiency or protein deficiency was also important. Hb levels varied with age, socioeconomic class, birthweight, sex, and rate of weight gain. The growth and health of 4 girls with homozygous sickle cell disease is mentioned.
\end{abstract}

In Jamaica, a developing country where there is still a high rate of mortality and malnutrition in infancy (McKenzie et al., 1967), there is little information about the incidence of anaemia. Ashcroft, Milner, and Wood (1969) studied $\mathrm{Hb}$ levels in rural Jamaican infants, some of whom were attending welfare clinics, and suggested that minor degrees of iron and folic acid deficiency may be common.

This paper reports haematological findings in urban Jamaican infants throughout the first year of life.

\section{Methods}

A longitudinal study of growth and development of Kingston infants from birth to 12 months of age was carried out. The infants were selected by taking 300 consecutive births at the University Hospital of the West Indies, beginning in March 1967. Babies of university staff, non-Jamaicans, and those who did not intend to reside in Kingston were excluded. The resulting sample came from predominantly working class families, and $92 \%$ were of mainly Negro extraction, the remainder being of mixed Chinese, Indian, Negro, and White parentage. Further details of the conduct of the study, and anthropometric, developmental, dietary, and social data have been described elsewhere (GranthamMcGregor and Back, 1970a, b, 1971; GranthamMcGregor and Hawke, 1971; Grantham-McGregor, Desai, and Back, 1972; Grantham-McGregor and Desai, 1973).

Received 19 December 1973.
The infants were seen nine times during the year. Those who did not attend the clinic were visited at home, and all homes were visited at least once. Medical treatment was given whenever necessary, though no dietary advice was given unless the child's health appeared to be in jeopardy. Children were not given an iron preparation unless their $\mathrm{Hb}$ fell below $8 \mathrm{~g} / 100 \mathrm{ml}$.

Blood specimens were taken within 3 days of birth, at 6 weeks ( \pm 3 days), at 3 and 6 months of age ( \pm 1 week), and at 8,10 , and 12 months ( \pm 2 weeks). They were obtained by venepuncture at 10 months of age and by heel or finger prick at other times. All specimens were examined on the same day as they were taken. Hb levels were estimated by the cyanmethaemoglobin method against a certified cyanmethaemoglobin standard. A microhaematrocrit was performed at 10 and 12 months of age and the mean corpuscular $\mathrm{Hb}$ concentration (MCHC) estimated. At 10 months of age serum iron and latent iron binding capacity were estimated using a routine method based on that of Beale, Bostrom, and Taylor $(1961,1962)$. Hb electrophoresis using a vertical filter paper technique was also performed at this time.

The children were divided into 2 socioeconomic groups on the basis of their standard of housing and their mothers' and cohabiting fathers' occupations. By these criteria the 'upper' group were mainly lower middle class or better working class, and the 'lower' group were poorer working class.

\section{Results}

The distribution of $\mathrm{Hb}$ genotypes among the infants is shown in Table I. The group is too small to assess the incidence of genotypes in the total 
TABLE I

Distribution of $\mathrm{Hb}$ genotypes among 300 infants

\begin{tabular}{c|c|c}
\hline Hb genotype & No. of infants & $\begin{array}{c}\text { \% of those with } \\
\text { known genotypes }\end{array}$ \\
\hline AA & 231 & $85 \cdot 6$ \\
AS & 25 & $9 \cdot 3$ \\
AC & 7 & $2 \cdot 6$ \\
SS & 4 & $1 \cdot 5$ \\
SC & 2 & $0 \cdot 7$ \\
CC & 1 & $0 \cdot 4$ \\
Unknown & 30 & - \\
\hline Total & 300 & $(100 \cdot 1)$ \\
\hline
\end{tabular}

population. The $\mathrm{Hb}$ levels of the 7 children with genotypes SS, SC, and CC varied, some falling below the mean as early as 6 weeks, and all being below the mean by the end of the year (Table II). These children were excluded from further analyses.

In order to examine only 'normal' children, a further 37 children of low birthweight (below 2.5 $\mathrm{kg}$ ) or of multiple birth - both causes of anaemia in infancy-were excluded. A further 30 whose $\mathrm{Hb}$ genotype was not determined were also excluded. The results presented here refer to 226 children (118 boys and 108 girls) who were singletons of birthweight $2.5 \mathrm{~kg}$ or more and of $\mathrm{Hb}$ genotype $\mathrm{AA}, \mathrm{AS}$, or AC. 25 children with genotype AS and 6 with AC were included among this 'normal' group as all their other haematological findings were similar to those of children with genotype AA. At least $96 \%$ of the children in this group were seen at each scheduled clinic visit or by follow-up home visit, though technical problems caused some further loss of data.

Table III shows $\mathrm{Hb}$ levels during the year. Males had lower mean $\mathrm{Hb}$ levels than females at 6 weeks of age $(P<0.01)$; this trend continued for the rest of the year though the differences did not again reach significance. Mean $\mathrm{Hb}$ levels also varied with age, with the well-known primary fall from birth to 3 months and a secondary dip around 8 months.
TABLE III

Mean $\mathrm{Hb}$ levels during their first year of 226 singleton infants of birthweight $2.5 \mathrm{~kg}$ or more and of $\mathrm{Hb}$ genotype $A A, A S$, or $A C$

\begin{tabular}{|c|c|c|c|}
\hline Sex/age (mth) & No. & $\begin{array}{l}\text { Mean Hb level } \\
(\mathrm{g} / 100 \mathrm{ml})\end{array}$ & SD \\
\hline $\begin{array}{c}\text { Males (118) } \\
0 \\
1 \frac{1}{2} \\
3 \\
6 \\
8 \\
10 \\
12\end{array}$ & $\begin{array}{r}118 \\
115 \\
111 \\
114 \\
47 \\
100 \\
111\end{array}$ & $\begin{array}{l}19.5 \\
10.9 \\
10.7 \\
10.5 \\
10.0 \\
10.6 \\
10.6\end{array}$ & $\begin{array}{l}2 \cdot 2 \\
1 \cdot 4 \\
1 \cdot 3 \\
1 \cdot 2 \\
1 \cdot 0 \\
1 \cdot 3 \\
1 \cdot 4\end{array}$ \\
\hline $\begin{array}{c}\text { Females (108) } \\
0 \\
1 \frac{1}{2} \\
3 \\
6 \\
8 \\
10 \\
12\end{array}$ & $\begin{array}{r}107 \\
102 \\
104 \\
100 \\
38 \\
100 \\
96\end{array}$ & $\begin{array}{l}19.5 \\
11.5 \\
10.9 \\
10.7 \\
10.4 \\
10.7 \\
10.7\end{array}$ & $\begin{array}{l}2 \cdot 1 \\
1 \cdot 3 \\
1 \cdot 3 \\
1 \cdot 3 \\
1 \cdot 2 \\
1 \cdot 2 \\
1 \cdot 5\end{array}$ \\
\hline
\end{tabular}

Though the numbers were low at 8 months, the few children whose Hbs were measured then did not have lower $\mathrm{Hb}$ levels at 6 and 10 months than the other children, so the dip at 8 months was a real one.

There was little difference between the 2 socioeconomic groups throughout the first 6 months of life. From 8 months onwards the upper socioeconomic group had higher $\mathrm{Hb}$ levels than the lower group and the difference became significant by 12 months of age $(P<0.05)$. The relation existed in both sexes, but was stronger in boys.

The relation between weight gain and $\mathrm{Hb}$ level was examined. A very weak negative correlation $(\mathrm{r}=-0.21, \mathrm{P}<0.05)$ between weight gain during the first 3 months of life and $\mathrm{Hb}$ level at 3 months of age was found. A similar correlation was found between weight gain from 3 to 12 months of age and $\mathrm{Hb}$ level at 12 months $(\mathrm{r}=-0.16, \mathrm{P}<0.05)$. The mean $\mathrm{Hb}$ levels of 25 children who were 'underweight' at 12 months of age (by the definition

TABLE II

$\mathrm{Hb}$ levels $(\mathrm{g} / 100 \mathrm{ml})$ in 7 infants of genotype $S S, S C$, or CC

\begin{tabular}{|c|c|c|c|c|c|c|c|c|}
\hline \multirow{2}{*}{ Genotype } & \multirow{2}{*}{ Child } & \multicolumn{7}{|c|}{ Age (mth) } \\
\hline & & 0 & $1 \frac{1}{2}$ & 3 & 6 & 8 & 10 & 12 \\
\hline $\begin{array}{l}\text { SC } \\
\text { CC }\end{array}$ & $\begin{array}{l}\text { A } \\
\text { B } \\
\text { C } \\
\text { D } \\
\text { E } \\
\text { F } \\
\text { G }\end{array}$ & $\begin{array}{l}18 \cdot 0 \\
19 \cdot 4 \\
19 \cdot 8 \\
16 \cdot 5 \\
16 \cdot 0 \\
19 \cdot 8 \\
17 \cdot 2\end{array}$ & $\begin{array}{r}11 \cdot 8 \\
10 \cdot 8 \\
9 \cdot 4 \\
8 \cdot 5 \\
9 \cdot 6 \\
9 \cdot 3 \\
7 \cdot 1\end{array}$ & $\begin{array}{c}10 \cdot 1 \\
10 \cdot 3 \\
8 \cdot 0 \\
7 \cdot 2 \\
8 \cdot 1 \\
9 \cdot 9\end{array}$ & $\begin{array}{r}10 \cdot 7 \\
9 \cdot 5 \\
8 \cdot 6 \\
7 \cdot 8 \\
8 \cdot 4 \\
9 \cdot 7 \\
9 \cdot 2\end{array}$ & $\begin{array}{l}- \\
\overline{7 \cdot 7} \\
- \\
- \\
8 \cdot 2 \\
9 \cdot 0\end{array}$ & $\begin{array}{l}8 \cdot 8 \\
8 \cdot 7 \\
7 \cdot 9 \\
8 \cdot 3 \\
-7 \cdot 5 \\
9 \cdot 5\end{array}$ & $\begin{array}{l}9 \cdot 6 \\
-8 \cdot 7 \\
8 \cdot 8 \\
9 \cdot 1 \\
7 \cdot 4 \\
9 \cdot 0\end{array}$ \\
\hline
\end{tabular}


of an international working party in Jamaica, Lancet, 1970) were not significantly different from those of the group as a whole.

$\mathrm{Hb}$ levels were related to birthweight in both sexes in this study, even though small birthweight babies were excluded. Among boys the correlation between $\mathrm{Hb}$ level and birthweight was not significant at 3 months of age but was significant by 12 months of age $(r=0.35, P<0.01)$. In girls the correlation was significant at 3 months of age $(\mathbf{r}=\mathbf{0} \cdot \mathbf{2 0}, \mathbf{P}<\mathbf{0} \cdot 05)$ but there was no consistent relation later. These results are illustrated in Fig. 1 where the children have been divided into 2 groups according to birthweight.

We attempted to assess the effect of certain parasites upon $\mathrm{Hb}$ levels. The stools of 148 unselected infants were examined for parasitic cysts and ova at 10 or 12 months of age. In $88 \%$ of the stools no parasites were found. $8 \%$ had Giardia lamblia, 3\% had Ascaris lumbricoides, $1 \%$ Trichuris trichiura, and 1\% had both Ascaris and Trichuris. No hookworm was found. $\mathrm{Hb}$ levels in the few children in whom the findings were positive were not significantly lower than the rest.

Table IV shows means and SDs of MCHCs, serum iron, total iron binding capacity, uncombined iron binding capacity, and percentage saturation of transferrin at 10 months of age. Mean MCHCs at 12 months were similar to those at 10 months of age.

\section{Discussion}

This was a selected group of infants (all were born in hospital) containing a higher proportion of first borns than occurs in the general population. $\mathrm{Hb}$ levels of first-born babies were not different from the rest, however, and it appears that the large proportion of first borns did not bias the results. Any further bias due to the method of selection for hospital delivery would probably have been eliminated by the exclusion of low birthweight babies from the analyses.

There are very few reports on the growth and

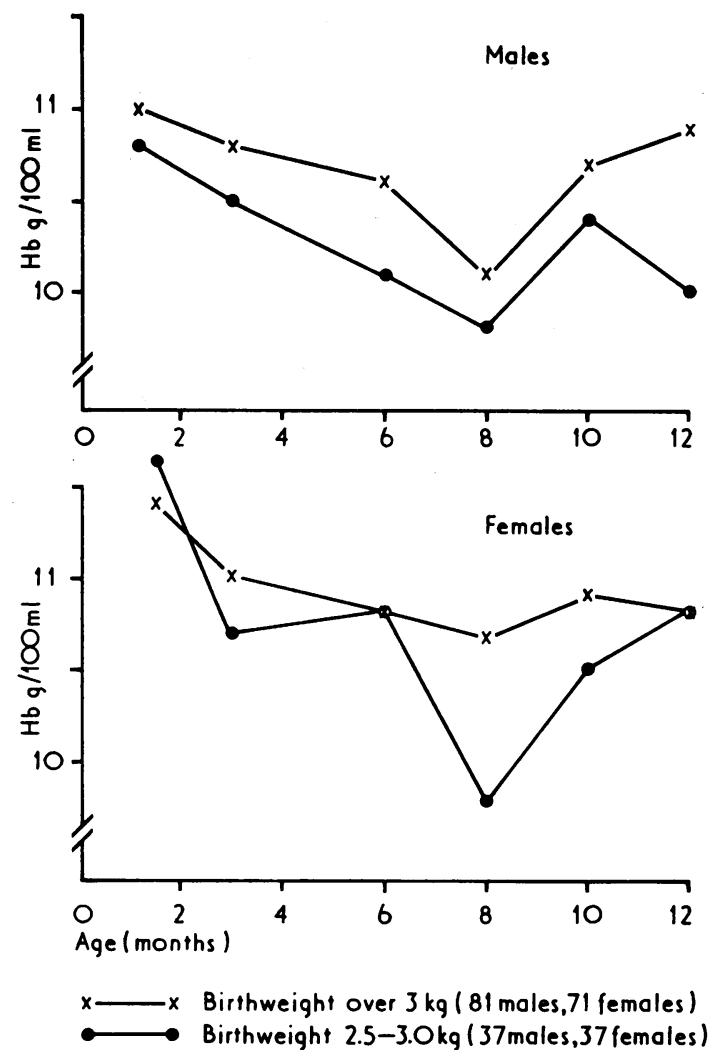

FIG. 1.-Mean Hb levels of infants of birthweight 2.5-3.0 $\mathrm{kg}$ compared with those of birthweight $>3 \mathrm{~kg}$.

health of infants with homozygous sickle cell disease, particularly before its clinical presentation. In this study the 4 girls who had the disease were comparable to the other children in both growth and health, their heights and weights being close to the median at 12 months of age, and the incidence of infection among them being no different from the rest of the group. Gray (1971) also reported

TABLE IV

Means and SDs of iron indices at 10 months of age, and percentage of anaemic children

\begin{tabular}{|c|c|c|c|c|c|}
\hline Iron index & No. & Mean & SD & $\begin{array}{l}\text { Definition of } \\
\text { anaemia }\end{array}$ & $\begin{array}{l}\text { Percentage of } \\
\text { anaemic children }\end{array}$ \\
\hline $\begin{array}{l}\text { MCHC } \\
\text { Serum iron }(\mu \mathrm{g} / 100 \mathrm{ml}) \\
\text { Total iron binding capacity }(\mu \mathrm{g} / 100 \mathrm{ml}) \\
\text { Uncombined iron binding capacity } \\
(\mu \mathrm{g} / 100 \mathrm{ml}) \\
\% \text { saturation of transferrin }\end{array}$ & $\begin{array}{l}134 \\
141 \\
141 \\
141 \\
141\end{array}$ & $\begin{array}{r}31 \cdot 1 \\
58 \cdot 3 \\
364 \cdot 6 \\
304 \cdot 7 \\
16 \cdot 1\end{array}$ & $\begin{array}{r}1 \cdot 5 \\
22 \cdot 6 \\
60 \cdot 0 \\
65 \cdot 1 \\
6 \cdot 9\end{array}$ & $\begin{array}{l}\text { Below } 31 \\
\text { Below } 50\end{array}$ & $\begin{array}{l}37 \\
43 \\
49\end{array}$ \\
\hline
\end{tabular}

$\star$ World Health Organization (1972). MCHC, mean corpuscular haemoglobin concentration. 
normal weights and heights in Jamaican children with sickle cell disease, but Booker, Scott, and Ferguson (1964) reported depressed weights after 4 months of age in Washington, D.C.

$\mathrm{Hb}$ levels in this study were compared with those found by Burman (1972) in a study in Bristol, U.K., in which low birthweight babies and twins were also excluded from analyses. The mean $\mathrm{Hb}$ levels of the Kingston children were lower than those of the Bristol children at all ages (Fig. 2). The dip which occurred in the $\mathrm{Hb}$ of the Kingston children at 8 months of age was not unlike the dip which was observed at 9 months of age in the Bristol data, which Burman attributed partly to depletion of iron stores. Ashcroft et al. (1969) found similarly low

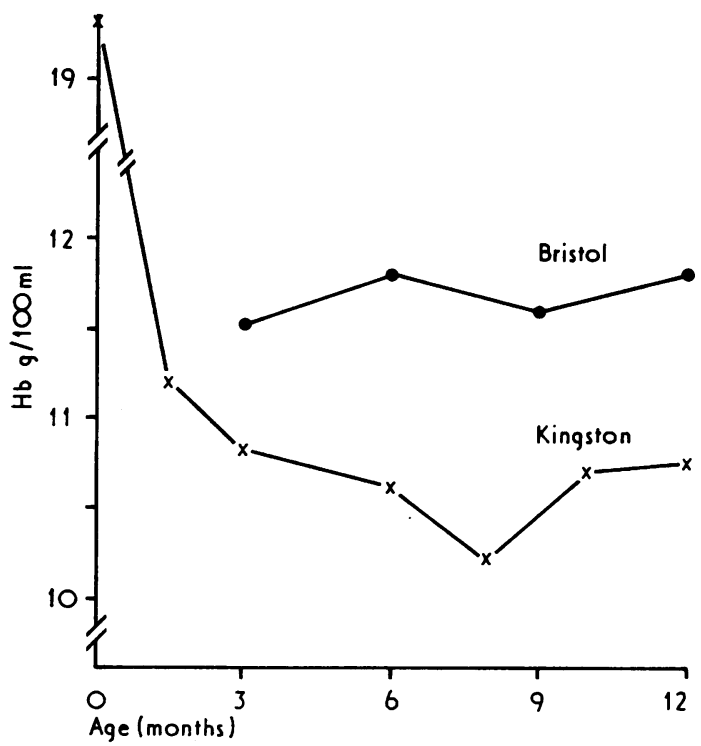

Fig. 2.-Mean Hb values of Kingston (Jamaica) and Bristol (U.K.) infants.

$\mathrm{Hb}$ levels in rural Jamaican children. It is surprising that Oppé (1964) reported even lower Hb levels in West Indian children attending a London hospital; it appears that the comprehensive health services in Britain have not reached these migrant children.

In this study females had higher $\mathrm{Hb}$ levels than males, a similar sex difference being reported by Burman (1972), and males gained slightly more weight than females during the year, the negative correlation we found between weight gain and $\mathrm{Hb}$ level partly explaining this sex difference. No correlation between weight gain and $\mathrm{Hb}$ level was found by Burman or by Beal, Meyers, and
McCammon (1962) in the U.S.A. It was surprising that the underweight children did not have lower Hbs than the rest, as presumably they were on poorer diets. However, the association between lower $\mathrm{Hb}$ levels and higher weight gains may provide a partial explanation.

In Kingston we found a relation between social class and mean $\mathrm{Hb}$ level, unlike the findings of Burman in the U.K., Lovric (1970) in Australia, and Kripke and Sanders (1970) in the U.S.A. However, it is unlikely that their lowest socioeconomic groups were so poor as ours, and it is possible that low $\mathrm{Hb}$ levels are only associated with low socioeconomic class when standards of living are very poor.

It is difficult to define anaemia in infancy by reference to $\mathrm{Hb}$ levels, though by most commonly accepted standards there was a high rate of anaemia among the children in this study. A WHO Technical Report (World Health Organization, 1972) suggested that the definition of anaemia in infancy should be a Hb level below $11 \mathrm{~g} / 100 \mathrm{ml}$. A Committee on Nutrition (1969) cited Sturgeon's work (1958) and suggested that a level of $12 \mathrm{~g} / 100$ $\mathrm{ml}$ was probably optimal in infancy and that levels down to $11 \mathrm{~g} / 100 \mathrm{ml}$ could be considered normal. Burman considered this lower level unrealistic and suggested levels of 10 or $9.5 \mathrm{~g} / 100 \mathrm{ml}$. Fig. 3 shows the percentage of children in our study with Hb levels below 11,10 , and $9 \mathrm{~g} / 100 \mathrm{ml}$ at each age. There was a high incidence of anaemia, reaching a

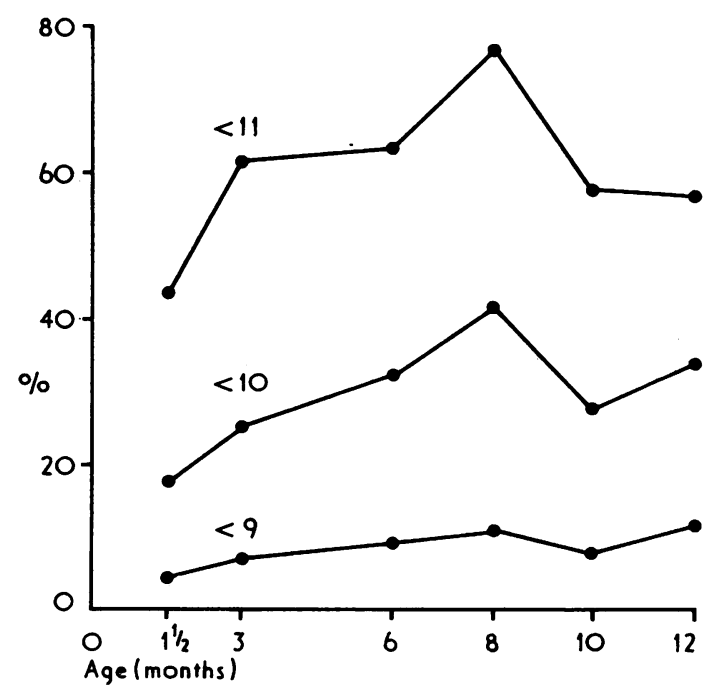

Fig. 3.-Percentage of infants with $\mathrm{Hb}$ values below 11,10 , and $9 \mathrm{~g} / 100 \mathrm{ml}$. 
peak at 8 months of age, with $76 \%$ of children below $11 \mathrm{~g} / 100 \mathrm{ml}$ and $41 \%$ below $10 \mathrm{~g} / 100 \mathrm{ml}$.

The normal range of serum iron in infants is not well documented. Bainton and Finch (1964) have shown that in adults erythropoeisis is limited by iron deficiency when the saturation of transferrin falls below $16 \%$. Sturgeon (1954), Hunter (1970), and Smith (1960) all quote different values. The WHO Technical Report (World Health Organization, 1972) referred to the need for standardized laboratory techniques and methods of sample selection, and suggested that serum iron values below $50 \mu \mathrm{g} / 100 \mathrm{ml}$, per cent. saturation of transferrin below 15, and MCHCs below 31 indicate iron deficiency. The high percentage of children with values below these critical levels is shown in Table IV. $\mathrm{Hb}$ levels at 10 months of age were positively correlated with per cent. saturation of transferrin and serum iron values $(r=0.44, P$ $<0.01$ for both results). It seems that the low $\mathrm{Hb}$ levels at 10 months of age were at least partly due to iron deficiency. The mean transferrin level in this study was low compared with other studies, but no correlation was found between $\mathrm{Hb}$ levels and transferrin levels. It is unlikely that blood loss was the cause of the high incidence of iron deficiency. The prevalence of intestinal parasites was low, and only a few children were fed on whole cow's milk, another possible cause of enteric blood loss (British Medical Journal, 1973).

In view of the low levels of $\mathrm{Hb}$ found as early as 3 months of age it appears that the iron stores at birth in these children were poor. The low mean birthweights found in this study (Grantham-McGregor et al., 1972) would have contributed to the low iron stores at birth, and there was no policy of late clamping of the cord which may have improved iron stores (Yao, Moinian, and Lind, 1969). There is conflicting evidence (reviewed by Smith, 1970) as to whether iron deficiency in pregnancy affects the fetus. The high incidence of iron deficiency anaemia $(24 \%$ of patients with $\mathrm{Hb}$ levels $<11 \mathrm{~g} / 100$ $\mathrm{ml}$ ) in women attending antenatal clinics at the University Hospital of the West Indies (Pathak, Wood, and Sorhaindo, 1967) might have been an additional cause of poor iron stores in the neonate.

The high incidence of anaemia later in the year was almost certainly partly due to poor iron intake or absorption. The diets of children in this study were generally poor (Grantham-McGregor and Back, 1970b), maize meal being the staple food of most weaning diets. Ashworth et al., (1973) showed that iron from this source is very poorly absorbed by Jamaican infants. Beresford, Neale, and Brooks (1971) have shown that iron absorption is reduced in the presence of fever, so that infection and fever in infants could be a cause of iron deficiency. In this study there was a high incidence of infections, particularly of gastroenteritis, and this may have reduced the amount of iron absorbed by the infants. It is also possible that folic acid deficiency contributed to the low Hb levels, as cases of severe folic acid deficiency anaemia are not uncommon in Kingston (MacIver and Back, 1960).

Though there is conflicting evidence as to the clinical significance of iron deficiency anaemia in infancy, Andelman and Sered (1966) showed a higher incidence of respiratory infections in children with iron deficiency, and recently Howell (1970) found that attentiveness and ability to sustain interest in a learning task were poor in iron-deficient preschool children compared with children who were not deficient. It seems worth while to investigate the possibility of reinforcing the diet of Jamaican infants with iron.

Professor E. H. Back, formerly of the Department of Paediatrics, University Hospital of the West Indies, initiated the study, and he and other members of the department gave valuable advice and help. We thank Nurse E. M. Buchanan, who helped with data collection, and laboratory technicians Mrs. Chambers, Miss Williams, Miss Dyer, and Miss Pitcan. The survey was carried out under a grant from the Josiah Macy, Jr. Foundation.

\section{REFERENCES}

Andelman, M. B., and Sered, B. R. (1966). Utilization of dietary iron by term infants: a study of 1,048 infants from a low socioeconomic population. American fournal of Diseases of Children, $111,45$.

Ashcroft, M. T., Milner, P. F., and Wood, C. W. (1969). Haemoglobin concentration, eosinophilia and intestinal helminths in children in rural Jamaica. Transactions of the Royal Society of Tropical Medicine and Hygiene, 63, 811.

Ashworth, A., Milner, P. F., Waterlow, J. C., and Walker, R. B. (1973). Absorption of iron from maize (Zea mays L.) and soya beans (Glycine hispida Max.) in Jamaican infants. British Fournal of Nutrition, 29, 269.

Bainton, D. F., and Finch, C. A. (1964). The diagnosis of iron deficiency anaemia. American fournal of Medicine, 37, 62.

Beal, V. A., Meyers, A. J., and McCammon, R. W. (1962). Iron intake, hemoglobin, and physical growth during the first two years of life. Pediatrics, 30, 518 .

Beale, R. N., Bostrom, J. O., and Taylor, R. F. (1961). Rapid incremental methods for the determination of serum iron and iron-binding capacity. Fournal of Clinical Pathology, 14, 488.

Beale, R. N., Bostrom, J. O., and Taylor, R. F. (1962). Improved rapid methods for the determination of iron content and binding capacity of serum. Fournal of Clinical Pathology, 15, 156.

Beresford, C. H., Neale, R. J., and Brooks, O. G. (1971). Iron absorption and pyrexia. Lancet, 1, 568.

Booker, C. R., Scott, R. B., and Ferguson, A. D. (1964). Studies in sickle cell anemia. XXII. Clinical manifestations of sickle cell anemia during the first two years of life. Clinical Pediatrics, 3, 111.

British Medical fournal (1973). Problems of iron-deficiency anaemia in infancy, 1, 437.

Burman, D. (1972). Haemoglobin levels in normal infants aged 3 to 24 months, and the effect of iron. Archives of Disease in Childhood, 47, 261.

Committee on Nutrition (1969). Iron balance and requirements in infancy. Pediatrics, 43, 134. 
Grantham-McGregor, S. M., and Back, E. H. (1970a). Breast feeding in Kingston, Jamaica. Archives of Disease in Childhoud, 45, 404.

Grantham-McGregor, S. M., and Back, E. H. (1970b). A note on infant feeding in Kingston. West Indian Medical fournal, 19, 111.

Grantham-McGregor, S. M., and Back, E. H. (1971). Gross motor development in Jamaican infants. Developmental Medicine and Child Neurology, 13, 79.

Grantham-McGregor, S. M., and Desai, P. (1973). Head circumferences of Jamaican infants. Developmental Medicine and Child Neurology, 15, 441.

Grantham-McGregor, S. M., Desai, P., and Back, E. H. (1972). A longitudinal study of infant growth in Kingston, Jamaica. Human Biology, 44, 549.

Grantham-McGregor, S. M., and Hawke, W. A. (1971). Developmental assessment of Jamaican infants. Developmental Medicine and Child Neurology, 13, 582.

Gray, R. H. (1971). Clinical features of homozygous SS disease in Jamaican children. West Indian Medical fournal, 20, 60.

Howell, D. A. (1970). Iron Nutrition in Infancy, p. 24. Report of the 62nd Ross Conference on Pediatric Research. Ross Laboratories, Columbus.

Hunter, R. E. (1970). Iron Nutrition in Infancy, p. 18. Report of the 62nd Ross Conference on Pediatric Research. Ross Laboratories, Columbus.

Kripke, S. S., and Sanders, E. (1970). Prevalence of iron-deficiency anemia among infants and young children seen at rural ambulatory clinics. American fournal of Clinical Nutrition, 23, 716.

Lancet (1970). Leader. Classification of infantile malnutrition, 2, 302.

Lovric, V. A. (1970). Normal haematological values in children aged 6 to 36 months and socio-medical implications. Medical fournal of Australia, 2, 366.
MacIver, J. E., and Back, E. H. (1960). Megaloblastic anaemia of infancy in Jamaica. Archives of Disease in Childhood, 35, 134.

McKenzie, H. I., Lovell, H. G., Standard, K. I., and Miall, W. E. (1967). Child mortality in Jamaica. Milbank Memorial Fund Quarterly, 45, 303.

Oppé, T. E. (1964). Medical problems of coloured immigrant children in Britain. Proceedings of the Royal Society of Medicine, 57, 321.

Pathak, U. N., Wood, J. K., and Sorhaindo, B. A. (1967). Anemia of pregnancy treated with single intravenous dose of irondextran. Obstetrics and Gynecology, 29, 500.

Smith, C. H. (1960). Blood Diseases of Infancy and Childhood, p. 174. Mosby, St. Louis.

Smith, N. J. (1970). Iron Nutrition in Infancy, p. 32. Report of the 62nd Ross Conference on Pediatric Research. Ross Laboratories, Columbus.

Sturgeon, P. (1954). Studies of iron requirements in infants and children. I. Normal values for serum iron, copper and free erythrocyte protoporphyrin. Pediatrics, 13, 107.

Sturgeon, P. (1958). Studies of iron requirements in infants and children. In Iron in Clinical Medicine, p. 183 . Ed. by R. O. Wallerstein and S. R. Mettier. University of California Press, Berkeley.

World Health Organization (1972). Nutritional anaemias : report of a WHO Group of Experts. World Health Organization Technical Report Series, 503.

Yao, A. C., Moinian, M., and Lind, J. (1969). Distribution of blood between infant and placenta after birth. Lancet, $2,871$.

Correspondence to Mrs. P. Desai, M.R.C. Epidemiology Unit, University of the West Indies, Mona, Kingston 7, Jamaica, W.I. 